

\section{ÍNDICE}

\section{ÁMBITOS PERSONALES PERSONAL ÁMBITOS}

Crisis de Venezuela: Análisis y perspectivas según los titulares de la prensa argentina, española y china

Venezuela's crisis: Analysis and perspectives in the headlines of Argentine, Spain and China press

Hui Feng Liu

Tratamiento informativo de la violencia de género: asesinatos de mujeres. Análisis de la agencia EFE

Informative treatment of gender violence: murders of women. Analysis of the press agency EFE Rosa Rodríguez Cárcela, Agustín López Vivas

MONOGRAFICOS MONOGRAPHS

Presentación Monográfico. El universo transmedia de los medios de comunicación universitarios: acción dentro y fuera del aula en la sociedad postdigital

Antonia Isabel Nogales-Bocio, Ángels Álvarez villa

El papel transformador de la radio universitaria en materias teóricas ajenas a la comunicación

The transformative role of college radio in theoretical subjects outside communication

Miguel Ángel Díaz Monsalvo

La radiodifusión universitaria: acción discursiva radiofónica para la divulgación de la ciencia University Radio Broadcasting: Radiophonic Discursive Action for the Science Popularization Jorge Sadi Durón, Joel Zapata Salazar

El uso corporativo de Instagram en las universidades privadas españolas. Estudio comparativo de treinta y cinco universidades

The corporate use of Instagram in spanish private universities. Comparative analysis of thirty-five private universities 
La radio universitaria como herramienta de inclusión social: OndaCampus en contextos como la cárcel y barrios desfavorecidos

The university radio as a tool for social inclusion: OndaCampus in contexts like the prison and disadvantaged neighborhoods

Leonor Real Adame, Daniel Martín-Pena, Macarena Parejo Cuéllar

Hacer radio universitaria en la era de YouTube: uso de la plataforma de vídeos a demanda en el contexto mexicano

Make college radio in the age YouTube: use of video on demand platform in the Mexican context Marina Vázquez Guerrero

\section{ARTÍCULOS ARTICLES}

O impresso e o digital nos modelos de negócios de jornais locais: uma análise do Sermos Galiza

The press and digital in business models from local media: Analysis of newspaper Sermos Galiza

Giovanni Ramos

Publicidad y cáncer en la prensa escrita (1903-1912)

Advertising and cancer in the written press (1903-1912)

Laura Almudéver-Campo, Ramón Camaño-Puig

Game rules vs. fandom. How Nintendo's Animal Crossing fan-made content negotiates the videogame meanings

Las reglas del juego vs. el fandom. Cómo el contenido hecho por fans de Nintendo Animal Crossing negocia los significados del videojuego

Jose A. Moreno

La comedia de situación y su análisis textual: evolución de los elementos constructivos del formato

The sitcom and its textual analysis: evolution of the constructive elements of the format

Darío Martín Sánchez

Análisis del discurso emocional de Donald Trump en la campaña electoral de $\mathbf{2 0 1 6}$ Analysis of Donald Trump's emotional speech on the 2016 election campaign 
Innovar, comunicar y transformar (en) la Universidad

Innovate, communicate and transform (at) the University

María Sofía Bernat

288-292

Transparencia en los medios: Un requisito imprescindible para medir la rentabilidad social en radio y televisión

Transparency in the media: An essential requirement to measuresocial profitability in radio and television

Amanda Salazar

Los estudios feministas en comunicación: representación de las mujeres en la revolución tecnológica

Feminist studies in communication: representation of women in the technological revolution 


\title{
Tratamiento informativo de la violencia de género: asesinatos de mujeres. Análisis de la agencia EFE
}

\author{
Informative treatment of gender violence: murders of women.
} Analysis of the press agency EFE

Rosa Rodríguez Cárcela, Universidad de Sevilla de Sevilla, Américo Vespucio $n^{\circ} 27,41092-S e v i l l a$

rmaria.rodriguez@juntadeandalucia.es | Orcid: https://orcid.org/0000-0003-1718-7564

\section{Agustín López Vivas, Universidad de Sevilla, Universidad de Sevilla, Américo Vespucio $n^{\circ} 27,41092-S e v i l l a$}

agustin.lopez.vivas97@gmail.com | Orcid: https://orcid.org/0000-0002-3755-1231

DOI: http://dx.doi.org/10.12795/Ambitos.2020.i47.02

\begin{abstract}
Resumen
Este trabajo de investigación realiza un análisis periodístico sobre el tratamiento de los asesinatos de mujeres, englobados dentro de los delitos de violencia de género. El estudio se centra en los nueve asesinatos cometidos en España durante julio de 2019 -el mes con mayor número de muertes- y su reflejo en EFE, puesto que los contenidos difundidos por esta agencia de noticias ejercen influencia en el resto de medios de comunicación. Dichos homicidios se denominan genéricamente violencia machista. Este tipo de violencia, aunque tiene muchos supuestos, se convierte en noticia cuando matan a una mujer. Las conclusiones ponen de manifiesto que los datos que se divulgan mayoritariamente sobre las víctimas mortales se centran en el número que ocupan dentro de las cifras oficiales de la Delegación del Gobierno para la Violencia
\end{abstract}


de Género, la edad y la causa que les ha provocado la muerte a manos de sus asesinos. Más de la mitad de las informaciones analizadas no facilitan los nombres de las asesinadas, ni tampoco sus profesiones. Este trato informativo tiende a uniformarse en el resto de medios, contribuyendo a la invisibilidad de estas mujeres, las cuales se convierten en meros números estadísticos. Además, las fuentes que se utilizan para elaborar estos casos son en más de un $85 \%$ oficiales, ofreciendo una visión muy institucionalizada frente a otras versiones más expertas o cercanas al entorno de las fallecidas. Dada la actualidad de esta temática y su frecuente difusión en los medios, se plantea la necesidad de dar a conocer estos resultados y proponer una mayor implicación a través del ejercicio de un periodismo de investigación sobre la criminalidad de género.

This research work carries out a journalistic analysis on the treatment of the murders of women, classified as crimes of gender violence. The study focuses on the nine murders committed in Spain along July 2019 - the month with the highest number of deaths - and their treatment by the EFE news agency, since the reports disseminated by this news agency influence the rest of the media. These homicides are generically called male-chauvinist violence. This type of violence, although it has many varieties, becomes news when a woman is killed. The conclusions show that the data that are mostly disclosed about the deathly victims focus on the number they occupy within the official figures of the Government's Office for Gender-based Violence, the age and the cause of death of the victim. More than half of the news analyzed does not provide the names of those killed, nor their professions. This informative treatment tends to become uniform in the rest of the media, contributing to the invisibility of these women, which become mere statistical data. In addition, the sources used to elaborate these news are official sources in more than $85 \%$, offering a very institutionalized vision compared to other more expert versions or close to the environment of the deceased. Considering the topicality of this issue and its frequent dissemination in the media, there is a need to publicize these results and propose greater involvement through the exercise of investigative journalism on gender crime.

Palabras clave: Violencia machista, asesinatos, mujeres, medios comunicación, violencia género

Keywords: Macho violence, murders, women, comunication means, gender violence

\section{INTRODUCCIÓN}

El asesinato de mujeres a manos de sus maridos, novios o ex parejas es el delito más grave dentro de la violencia de género. Es el extremo del maltrato al que se puede llegar y que tiene mayor repercusión mediática, dada la gravedad y la alarma social que despierta. 
Como bien ha reflexionado Ramón Reig, en la actualidad los medios, cuando se cometen estos cobardes actos de violencia extrema, se limitan frecuentemente a informar sobre que:

(...) han matado a una mujer y ésta hace ya el número mil y pico desde que se empezaron a contar los asesinatos. Punto. Suma y sigue. La asesinada es un simple número, ni los responsables de gestionar la vida de un país ni los medios de comunicación se detienen en más (2019).

Aquí se encuentra la clave del trabajo de investigación. Este importante tema tiende a tratarse de manera superficial, como un mero número estadístico, pero no se profundiza en el cómo y por qué de la noticia, de cada caso. Es poco frecuente realizar un periodismo de investigación sobre la criminalidad de género, que no sólo incluya los asesinatos -los más mediáticos-, sino también otros delitos graves que afectan a la integridad física de las mujeres. Tampoco es habitual la emisión o publicación de reportajes que indaguen en los motivos que provocan que determinados hombres quiten la vida de sus esposas o compañeras sentimentales. Apenas existen programas televisivos, secciones en la prensa y espacios radiofónicos especializados en estos crímenes y en la violencia contra la mujer en general.

En los medios de comunicación cada vez que se producen uno de estos asesinatos se tiende a informar de la misma manera, a uniformar contenidos, con datos similares. Cada asesinato se convierte en un número, en una cifra oficial, no en un caso personal, ya que a la víctima mortal apenas se le da visibilidad. El tratamiento periodístico que se ofrece -especialmente evidente en los telediarios-, se ha convertido en un formulario oficial, donde el esquema se repite una y otra vez: asesinada una mujer..., según los vecinos..., no consta que hubiera denuncia por malos tratos..., el ayuntamiento ha convocado una concentración decretando dos días de luto..., con este nuevo asesinato son ya "X" las víctimas desde que se contabilizan en el 2003. No obstante, la prensa local (tanto digital como escrita) sí suele facilitar una información más detallada y mejor elaborada, con datos más cercanos de las mujeres y los agresores, acudiendo a fuentes informativas próximas a las víctimas. Aunque posteriormente no es común que los medios en general dediquen sus esfuerzos a realizar los necesarios seguimientos de los casos, investigando al respecto.

La redacción de los crímenes denominados machistas tiende, en general, a convertirse en una plantilla informativa donde se rellenan una serie de preguntas normalizadas en las que se indica la edad de la mujer, cómo fue asesinada y el número total que ocupa dentro de la lista de víctimas que han muerto a lo largo del año en España. La estadística oficial prima sobre otro tipo de tratamiento más periodístico que investigue sobre estos casos y explique, consultando fuentes 
expertas, las causas de fondo. Por desgracia, los medios de comunicación están contribuyendo a la normalización informativa de estas conductas criminales.

El Gobierno de España facilita anualmente, desde el año 2003, estadísticas sobre víctimas mortales de la violencia de género. Las variables que aparecen son la evolución del número de mujeres asesinadas, las de sus características sociodemográficas y las de sus agresores y las denuncias previas y órdenes de protección, así como del quebrantamiento de las órdenes y suicidios de los asesinos. Sin embargo, no recogen la variable de las principales motivaciones de estos asesinatos. En otros países europeos se realizan estudios más rigurosos, usando la criminología, como por ejemplo el Ministerio del Interior del Gobierno de Francia que elabora estadísticas donde sí investigan las causas para prevenir la violencia en el entorno familiar o de pareja.

Estos datos estadísticos en manos de los medios de comunicación ayudan a difundir una cruda realidad social, pero si se utilizan meramente como porcentajes y números sin ir más allá de las cifras, el periodismo pierde su esencia y se convierte en un simple transmisor de información político-institucional lleno de mensajes huecos. El complemento a las estadísticas debe convertirse en un trabajo de análisis e investigación que explique a la gente este tipo de criminalidad. La prensa tiene como obligación realizar las críticas y el contrapoder necesarios a un sistema político, judicial y policial imperfecto, falto de recursos y en ocasiones desgraciadamente ineficaz.

Con este trabajo de investigación queremos dejar patente que los medios deben implicarse más en la violencia de género, difundiendo sus diferentes supuestos, especialmente cuando se comenten asesinatos. Es necesario profundizar y crear más espacios y secciones sobre esta temática.

En el artículo nos centramos específicamente en el tratamiento informativo que hace la agencia EFE sobre esta temática, ya que la prensa y los medios audiovisuales suelen nutrirse diariamente de sus noticias e imágenes y son un reflejo de esta violencia.

\section{METODOLOGÍA}

En el mes de julio de 2019 se cometieron en España nueve asesinatos de mujeres a manos de sus maridos o ex parejas -el número de víctimas mortales más alto en este año-, y las estadísticas oficiales (Delegación del Gobierno para la Violencia de Género) indican que dicho mes está considerado el más sangriento desde que empezaron a registrarse los crímenes de género en 2003. Así 104 mujeres fueron asesinadas en julio, lo que supone el $10,2 \%$ del total.

Para elaborar este trabajo hemos estudiado el tratamiento informativo dado por la agencia de noticias $\mathrm{EFE}^{1}$, durante julio de 2019 , sobre esta temática. Para ello se han 
analizado todas las noticias publicadas en su página web durante ese periodo, así como el resto de información audiovisual añadida (fotografías y vídeos) que ha servido para complementar dicho análisis.

En concreto, se han examinado 21 noticias sobre estos nueve asesinatos y también se ha observado el material audiovisual que complementa las noticias, compuesto por 31 fotografías y 8 vídeos. Nos hemos centrado mayoritariamente en estos 60 documentos periodísticos (información textual, imágenes y audios) para la obtención de las conclusiones que nos han permitido ofrecer una aproximación sobre cuál es el tratamiento mediático actual.

Las variables analizadas que se han incluido son las siguientes: número de noticias publicadas, sección, titulares, datos de la víctima, datos del asesino, causa de la muerte, motivo o móvil (si se explican o no las motivaciones o factores que determinan estas conductas asesinas), fuentes, fotos y vídeos (información audiovisual), lenguaje (terminología empleada sobre esta temática), utilización de cifras y mención a medidas preventivas (si se difunden o no medidas de carácter preventivo en las informaciones).

También se han consultado otras fuentes como la Estadística de Víctimas Mortales por Violencia de Género, publicada en la web de la Delegación del Gobierno para la Violencia de Género (Ministerio de la Presidencia, Relaciones con las Cortes e Igualdad). Según aclara dicha fuente, las cifras se refieren a mujeres asesinadas en los términos que recoge el artículo 1 de la Ley Orgánica 1/2004, de 28 de enero, de medidas de protección integral contra la violencia de género. Los datos que se pueden consultar son desde el año 2003 en adelante. De 2003 a 2005 proceden del Instituto de la Mujer, que se basaba en la información facilitada por los medios de comunicación. Los datos a partir de enero de 2006 provienen de la propia Delegación y recogen la información suministrada por las Delegaciones y Subdelegaciones del Gobierno y, desde su creación en 2007, de las Unidades de Coordinación y Unidades de Violencia contra la Mujer.

Asimismo, hemos recabado declaraciones tanto de periodistas que han cubierto informativamente alguno de los crímenes estudiados (caso de una redactora del periódico provincial de Lugo El Progreso) como de otras que ofrecen su opinión en representación de la Asociación de Periodistas Gallegas. Además, se han conseguido otras importantes fuentes orales como son los testimonios de familiares de una de las mujeres asesinadas, que han preferido no identificarse para permanecer en el anonimato.

Todo ello complementado con la aportación de otras fuentes bibliográficas, procedentes de libros, revistas científicas, periódicos y tesis doctorales relacionadas con la temática del estudio. 


\section{TRATAMIENTO INFORMATIVO EN EFE}

\subsection{Relación de asesinatos cometidos en julio de $\mathbf{2 0 1 9}$}

En este apartado vamos a analizar el tratamiento informativo que hace EFE durante el mes de julio de 2019, recogiendo los datos facilitados por la agencia. Hay que aclarar que la mayoría de los nombres de las víctimas que encabezan los asesinatos no se han conseguido de esta agencia de noticias, puesto que pocas veces se citan, sino de El Español ${ }^{2}$. Estudiamos a continuación caso a caso, realizando una descripción detallada de los nueve asesinatos.

\subsubsection{Asesinato 1. Piedad Cruz (Rute, Córdoba), 2 de julio.}

- Número de noticias publicadas. Un total de tres noticias los días 2, 3 y 4.

- Titulares. "Mata a su mujer en Rute (Córdoba) y se entrega en Madrid con sus dos hijos", "La mujer asesinada en Rute sufrió un traumatismo severo en la cabeza" y "Prisión sin fianza para el detenido por matar a su mujer en Rute (Córdoba)", respectivamente.

- Datos de la víctima. Piedad Cruz, de 42 años, asesinada a martillazos en su casa por el marido. Tenían dos hijos menores en común. No había puesto denuncia. Sí se cita nombre y primer apellido. No figura la profesión.

- Datos del asesino. Juan R.G., de 42 años. Huyó desde Rute a Madrid con sus hijos. Fue detenido en la capital española, después de avisar a la policía y confesar el crimen. No le constaban antecedentes. Se le imputa un delito de homicidio.

- Causa de la muerte. Martillazos.

- Motivo/Móvil. No se menciona.

- Fuentes utilizadas. La primera noticia de EFE se elabora citando "fuentes de la investigación", además de otras de tipo institucional (la consejera de Igualdad de la Junta de Andalucía y el alcalde de Rute). La fuente de la segunda noticia publicada sobre este caso es el Tribunal Superior de Justicia de Andalucía (TSJA) que señala que la causa del fallecimiento fue traumatismo craneoencefálico severo, motivado por golpes de martillo. La última noticia se nutre con las informaciones facilitadas por el Tribunal Superior de Justicia de Madrid (decreta su ingreso en la cárcel) y la Delegación del Gobierno para la Violencia de Género (datos estadísticos). 
- Fotos/Vídeos. La primera noticia va complementada por una foto y un vídeo, de una duración de 00:55 minutos, en los que una locutora relata los hechos (imágenes de la detención del homicida, acompañado por la Policía Nacional, del portal de la casa familiar y de la fachada del Ayuntamiento con las banderas en señal de luto). Las imágenes de la detención han sido facilitadas por la Policía y no se ve el rostro del autor confeso, ya que sólo figura de espaldas. En la segunda -con el pie de foto "Concentración en Córdoba contra el asesinato machista en Rute"-, aparece en primer plano una imagen de una mujer portando un cartel que dice "Negar el machismo MATA". La tercera información lleva la misma fotografía publicada del día 2 donde, al igual que en la primera, se observa a la Guardia Civil con una lona desplegada en la puerta de la vivienda donde se produjo el crimen. En este caso, en el pie de foto se aclara que "Agentes de la Guardia Civil despliegan una lona para tapar el traslado del cuerpo sin vida de la mujer de 42 años asesinada presuntamente por su marido".

- Lenguaje. Expresiones de corte político-institucional donde los políticos muestran "el rechazo más absoluto", "una condena firme", la "solidaridad" ante las familias. Los términos más habituales que se utilizan en el desarrollo de las noticias para calificar este suceso son crimen machista y violencia machista. Palabras como mujer, hombre, pareja, detenido, estadística, víctima, denuncias y Guardia Civil son las más repetidas. Con motivo de la concentración convocada por las instituciones, se indica la expresión "...ante un nuevo caso de violencia machista".

- Utilización de cifras. Se recoge en la noticia del día 2, en sus últimos párrafos, que "de confirmarse este crimen machista serían 27 las mujeres asesinadas por sus parejas o ex parejas en lo que va de año y 1.002 desde 2003, cuando empezaron a registrarse estos asesinatos". En la segunda noticia no se mencionan. En el último párrafo de la noticia del 4 se recoge que la Delegación del Gobierno para la Violencia de Género confirmó que "el asesinato de Piedad Cruz, es un crimen machista, el número 27 de este año y el 1.002 desde que comenzaron a registrarse las estadísticas en 2003". Al final del vídeo la locutora concluye diciendo: "De confirmarse este crimen machista sería el tercero en la provincia de Córdoba en menos de un mes".

- Medidas preventivas. Al final de la noticia del día 2 se recuerda, a modo de aviso, que el 016 atiende a todas las víctimas las 24 horas del día y en 51 idiomas diferentes. Una llamada que no deja rastro en la factura, si bien hay que borrarla del registro del teléfono móvil. También que los menores pueden dirigirse al teléfono de la Fundación ANAR 9002020 10, y los ciudadanos que sean testigos de alguna agresión deben llamar al 112. En la noticia del día 4 se 
informa que el Juzgado de Violencia sobre la Mujer de Madrid ha prohibido al asesino confeso acercarse a sus hijos a menos de 500 metros y comunicarse. También ha ordenado su ingreso en prisión.

\subsubsection{Asesinato 2. Monika Asenova. Sala de los Infantes (Burgos), 8 de julio.}

- Número de noticias publicadas. La agencia difundió dos informaciones los días 8 y 9.

- Titulares. "Asesinada una mujer en Burgos por su pareja, ya detenido" y "Detenido el cuñado de la asesinada en Burgos acusado de maltratarla también".

- Datos de la víctima. Monika A.A., mujer búlgara de 28 años, fallecida tras ser apuñalada por arma blanca en una vivienda por su "pareja estable". Tenía dos hijas menores. Ocupó el puesto de suplente en la candidatura municipal con la que el PP concurrió en los comicios en Salas de los Infantes y trabajaba en un supermercado del pueblo. No había denuncias previas. Fue asesinada en el interior de la vivienda en la que ya no residían, debido a un incendio ocurrido el 28 de junio pasado, y que ahora se investiga tras archivarse en un primer momento. La Guardia Civil la encontró aún viva en la calle e investiga si se cayó o la tiró el autor confeso.

- Datos del asesino. Pareja de la víctima, de 39 años, también de nacionalidad búlgara y del que no se facilita su nombre. Se ha entregado voluntariamente a la Guardia Civil y ha reconocido los hechos. El hombre fue detenido en 2011 por violencia machista, pero quedó en libertad.

- Causa de la muerte. Apuñalada con arma blanca.

- Motivo/Móvil. No se menciona. No obstante, la segunda noticia deja claro que sufría asiduamente maltrato físico.

- Fuentes. Según los vecinos y la Guardia Civil, la pareja "estaba perfectamente integrada en Salas de los Infantes, localidad en la que viven desde hace varios años, y ambos tenían trabajo". Otras fuentes vecinales precisaron a EFE que el autor confeso trabajaba de forma esporádica para el Ayuntamiento de la localidad. El subdelegado del Gobierno en Burgos informa que no hubo denuncia por parte de la mujer, aunque en 2011 se produjo un "conato de violencia de género" y no se activó el protocolo correspondiente. Esta fuente oficial también aporta el dato, recogido el día 9, que tanto el marido como el cuñado ejercían la violencia verbal y física contra la mujer de forma habitual en el hogar, por lo que todo lo que ocurría quedaba en un plano íntimo y, al 
parecer, no lo conocían más personas. También se añade una fuente política, como es la del presidente del Gobierno en funciones, Pedro Sánchez, que en su cuenta personal de Twitter dice: "No vamos a parar hasta acabar con esta lacra. Debemos hacerlo juntos y juntas y debemos hacerlo ya".

- Fotos/Vídeos. El día 8 se publican tres fotos (dos con imágenes de la Guardia Civil en el exterior de la vivienda donde se produjo el suceso) y un vídeo en los que una locutora, durante 00:58 minutos, cuenta los hechos del crimen con imágenes exteriores de la casa donde falleció la víctima, así como de agentes y furgones de la Guardia Civil y una ambulancia del Instituto de Medicina Legal.

- Lenguaje. Violencia machista y crimen machista son los términos utilizados para denominar este nuevo asesinato. Las palabras que más se repiten son mujer, pareja, víctima, Guardia Civil y denuncias. En este caso no se recogen declaraciones político-institucionales, calificando los hechos.

- Utilización de cifras. Las dos noticias en su desarrollo final añaden las siguientes:

El crimen machista, el 50 que se produce en Castilla y León desde que en 2003 se inició su registro, el segundo de este año en la comunidad y el 28 de España, ha provocado la repulsa unánime de partidos e instituciones, con la declaración de tres días de luto por parte del Ayuntamiento de Salas, que además ha convocado una concentración para esta tarde (día 8).

La Delegación del Gobierno para la Violencia de Género ha confirmado este martes que el asesinato de Monika A.A. es un crimen machista, el número 28 de este año y el 1.004 desde que comenzaron a registrarse las estadísticas en 2003. De las 28 mujeres asesinadas, solo cuatro habían denunciado al agresor, el $14,28 \%$ (día 9).

En el vídeo que acompaña a la noticia del día 8, al final de la narración informativa, se dice:

Con este caso, confirmado de violencia machista, se elevan a medio centenar las mujeres asesinadas por violencia de género en Castilla y León desde que se inició el registro en el 2003. Se trata del segundo caso de violencia machista en la comunidad este 2019.

- Medidas preventivas. La información del 9 de julio indica que se ha detenido al cuñado de la víctima como presunto autor de maltrato habitual hacia la mujer. También se menciona en la noticia que el representante gubernamental en Burgos ha hecho un llamamiento a las personas del entorno de domicilios 
donde sospechen que se están produciendo este tipo de situaciones "para que las denuncien y conseguir así que no queden impunes o impedir llegar a situaciones irreversibles, como la de Monika".

\subsubsection{Asesinato 3. María Asunción (Maisú) Pérez Ibarra. Elche (Alicante), 13 de julio.}

- Número de noticias publicadas. Un total de 3. El 13 de julio EFE publica dos noticias, una en la que propiamente se informa sobre el asesinato de una mujer cometido en el municipio alicantino de Elche y otra que recoge las declaraciones vía Twitter del presidente del Gobierno. El 15 de julio la agencia difunde otra información sobre este caso.

- Titulares. Los titulares del día 13 son: "Un hombre mata a su mujer 10 días después de iniciar el trámite de separación" y "Pedro Sánchez, ante el nuevo crimen machista de Elche: 'Insoportable'". El titular del 15 es: "Dictan el ingreso en prisión del hombre detenido por matar a su mujer en Elche".

- Datos de la víctima. Mujer de 47 años asesinada con arma blanca por el marido en el garaje de la vivienda familiar, madre de dos hijos de 17 y 21 años. La agredió a primera hora de la mañana cuando ella se marchaba a trabajar.

- Datos del homicida. Es el marido y padre de los hijos, hombre español de unos 50 años, detenido después de confesar el crimen. La causa está abierta por un delito de asesinato.

- Causa de la muerte. Heridas mortales de arma blanca.

- Motivo/Móvil. No se menciona directamente, pero tanto en el titular de la primera noticia del día 13 como al principio del texto se destaca el hecho de que fue asesinada "tan sólo diez días después de que hubieran iniciado los trámites de separación y pasados tres días de que ya no estuvieran residiendo juntos". También se recoge este hecho en la noticia del día 15.

- Fuentes. Las de la noticia del día 13 son mayoritariamente políticas, provenientes de declaraciones de la vicepresidenta del Gobierno, el presidente del Gobierno (tuit de su cuenta personal), el presidente de la Generalidad de Valencia, la consejera valenciana de Igualdad, el presidente del Partido Popular y la presidenta del PP de la Comunidad Valenciana, los cuales condenan el asesinato, dan el pésame a la familia y manifiestan su repulsa ante la violencia machista. Se complementa con otra fuente políticoinstitucional como es la subdelegada del Gobierno en Alicante que explica que la mujer había iniciado los trámites de separación y que la pareja se encontraba en un "momento crítico", confirmando que no constaban denuncias 
por malos tratos; y una sanitaria como es el Centro de Información y Coordinación de Urgencias de la Generalidad, que señala que los sanitarios que acudieron al lugar alertados por una llamada al 112 a las 7.31 de la mañana, practicaron a la mujer la reanimación cardiopulmonar avanzada, pero no lograron evitar que muriera.

El vídeo que complementa la primera noticia incluye a un testigo que, vuelto de espaldas a la cámara, dice que "salió el hombre con las manos manchadas de sangre y nos dijo que llamáramos a la Policía porque había matado a su mujer", así como las consabidas declaraciones de repulsa y condena de la subdelegada del Gobierno y del alcalde que nada añaden sobre las circunstancias del crimen. Las del 15 provienen del Tribunal Superior de Justicia de Valencia (judicial) y de "fuentes próximas al caso" (suelen ser policiales) y se ofrecen datos más técnicos del asesino confeso.

- Fotos/Vídeos. La primera noticia del día 13 se amplía con un vídeo de 02:22 minutos que recoge imágenes del lugar del asesinato, de un vecino que vio al asesino, de la manifestación de repulsa de los vecinos en el consistorio y declaraciones de políticos. La voz de un locutor en off cuenta los hechos, de forma parecida a la que recoge la nota. Una fotografía también muestra la entrada al garaje del domicilio de la mujer asesinada. La segunda noticia se ilustra con una imagen de archivo del presidente del Gobierno. La tercera noticia acompaña una foto con los familiares y vecinos a la entrada del domicilio de la mujer fallecida.

- Lenguaje. El término más utilizado es violencia machista, empleado tanto periodísticamente al redactar las noticias como políticamente al calificar el suceso. Se incluyen las expresiones de los políticos, condenando los hechos, al modo de "repulsa y lacra" (presidente nacional del PP), "condenar el asesinato" (vicepresidenta del Gobierno), "insoportable" (presidente del Gobierno) y "repugnancia e indignación" (presidente de la Generalidad de Valencia). Las palabras que más se repiten en las informaciones sobre este caso son: mujer, hombre, detenido, pareja, denuncias y asesinada. Llama la atención cómo los políticos que ostentan cargos de gobierno y con competencias en la materia, hacen manifestaciones ante los medios en las cuales se exculpan, de forma indirecta, de cualquier tipo de responsabilidad, implicando al resto de la sociedad como si ellos no fueran los que ejercen el poder ejecutivo y legislativo e influyen en las medidas judiciales y policiales. Como ejemplos tenemos las frases "Combatir sus causas es una lucha de todos y todas" (presidente de la Generalidad Valenciana, Ximo Puig, 13 de julio). También es poco alentador que un presidente de Gobierno despache este gravísimo tema con un frío tuit. Curiosamente la subdelegada califica de 
"insoportable" el asesinato, la misma palabra de condena que había empleado previamente el presidente de Gobierno en redes sociales.

- Utilización de cifras. En el segundo párrafo de la noticia se indica que esta mujer se convierte "en la trigésimo primera víctima mortal de violencia machista en España en lo que va de año. De ellas cinco vivían en la Comunidad Valenciana (tres en Alicante)". En el tercer párrafo se ofrecen las declaraciones de la vicepresidenta del Gobierno en el sentido de que con este nuevo fallecimiento son ya 1.006 mujeres las que se sabe que han muerto por violencia machista en España desde 2003. En el texto que acompaña al vídeo se vuelven a repetir las mismas cifras.

- Medidas preventivas. Se informa que el homicida ha sido detenido e ingresado en prisión provisional, comunicada y sin fianza. También que el magistrado ha acordado privar, de forma cautelar, al agresor de la patria potestad de su hijo menor de edad.

\subsubsection{Asesinato 4. Elena Peinado Gil (Cortes de la Frontera, Málaga), 17 de julio.}

- Número de noticias publicadas. Dos, el 17 y 18 de julio.

- Titulares. "La mujer hallada muerta en Málaga es la víctima 1007 de violencia machista" y "Vecinos de Cortes de la Frontera expresan su repulsa por el crimen machista".

- Datos de la víctima. Mujer de 47 años asesinada por su pareja con un rifle. Cadáver hallado a las 13.30 horas en la pedanía El Colmenar, de Cortes de la Frontera. No había presentado denuncia por maltrato.

- Datos del asesino. Pareja de la fallecida, militar retirado de 67 años, quien ha disparado con un rifle y después se ha suicidado. Su cuerpo fue encontrado en un lugar diferente al de la víctima. Tenía hijos de una relación anterior.

- Causa de la muerte. Tiroteada con un rifle.

- Motivo/Móvil. No se menciona.

- Fuentes. En la noticia se cita que "ha informado el Gobierno" de que se trata de la víctima 1.007 desde 2013. Las "fuentes de la investigación" indican que presuntamente el autor la ha matado con un rifle y que era un militar. Se reproducen los comentarios de la cuenta de Twitter del presidente del Gobierno, diciendo que hay que acabar con este tipo de asesinatos que no cesan y afectan a las mujeres, pero siendo el máximo responsable ejecutivo no 
dice cómo hacerlo. Entendemos que estas manifestaciones políticas no aportan informativamente nada al caso. El alcalde de Cortes apunta que, al parecer, después de cometer el crimen delante de la vivienda de la mujer se suicidó. En resumen, una fuente gubernamental no especificada (imaginamos que será la Subdelegación del Gobierno en Málaga) que aporta las cifras oficiales, otra política (nuevamente las declaraciones personales del presidente desde redes sociales), municipal (el alcalde aclara que el agresor disparó con un rifle y que la pareja llevaba conviviendo algo más de un año) y policial. Éstas dos últimas son las que realmente facilitan datos técnicos y de interés sobre el caso.

El vídeo que complementa la nota de agencia hace mención a que la investigación está en manos de la Guardia Civil, según la Subdelegación del Gobierno en Málaga, y aclara que es el Gobierno central el que aporta las cifras. También aparecen imágenes del alcalde que dice que la pareja "llevaba al menos un año juntos".

- Fotos/Vídeos. Se publican dos fotos, una por cada noticia. La imagen del día 17 muestra una vista del portal del edificio donde vivía la mujer y la del 18 una concentración ante el ayuntamiento integrada por la Guardia Civil, alcalde y demás personal municipal. La noticia de la primera noticia incorpora también un vídeo de 01:14 minutos, explicando brevemente los hechos. Lo más interesante son las imágenes que se ofrecen desde El Colmenar, puesto que se ve el entorno donde se cometió el crimen, los vecinos, los furgones de la Guardia Civil, agentes de la Benemérita, Protección Civil y un operario de los servicios funerarios introduciendo en el automóvil a uno de los cadáveres.

- Lenguaje. Violencia machista es la denominación más empleada para calificar este nuevo crimen. Las palabras más repetidas en los textos periodísticos son mujer, hombre, víctima mortal, asesinada, seguidas de pareja y registrar. En la noticia del 17 de julio se recogen las declaraciones vía tuit del presidente del Gobierno, indicando que se trata de "una violencia machista que no cesa y que nos indigna como sociedad" y que "hay que acabar ya con este machismo criminal que asesina a las mujeres". Un tipo de expresiones, a nuestro entender superficiales y de corte demagógico, puesto que no ofrecen medidas concretas para atajar dicha violencia. En la noticia del 18 la subdelegada del Gobierno, tras dar la nueva cifra, indica que se trata de "una tragedia tremenda que no debemos soportar". Como vemos, de nuevo se utiliza el plural como recurso expresivo para eludir la responsabilidad.

- Utilización de cifras. En la noticia del 17 de julio es muy claro el abuso de las cifras oficiales que sirven incluso para titular este crimen y que abren el primer 
párrafo de la información, al incidir en que este nuevo asesinato supone "la víctima mortal 1007 de la violencia machista desde que se empezaron a registrar los asesinatos en 2003". El protagonismo de la noticia se centra en la cifra, en el nuevo caso de violencia de género, pero no en la persona muerta de la que ni siquiera se dice su nombre. Los últimos párrafos también dan protagonismo a las estadísticas facilitadas por el Gobierno central: sólo en seis de los 32 asesinatos machistas de este año pesaba denuncia sobre el agresor (el $19,4 \%$ de los casos), en lo que va de año 24 menores han quedado huérfanos como consecuencia de los crímenes machistas, 250 desde 2013.

La información del día 18 aclara, en su tercer párrafo, que "se trata de la víctima número 40 de la violencia machista desde que se empezaron a registrar los asesinatos en 2003, y la tercera de este año en la provincia". Como observamos, la noticia está mal redactada e incluye un error, ya que al leerla da a entender que es la víctima número 40 desde 2003, pero realmente es la 32 en lo que va de 2019.

- Medidas preventivas. Al final de la noticia se recuerda que hay recursos como el 016 (atención a víctimas de violencia machista las 24 horas del día), el teléfono de la Fundación ANAR 900202010 (para los menores) y el 112 (para ciudadanos que sean testigos de agresiones).

\subsubsection{Asesinato 5. María del Carmen Vázquez Cereijo (Villalba, Lugo), 21 de julio.}

- Número de noticias publicadas. Un total de 3. Días 21, 22 y 23 de julio.

- Titulares. "Un hombre mata a su ex pareja en Villalba (Lugo) y después se suicida", "Decenas de personas se concentran en Villalba contra el último crimen machista" y "Plataforma Feminista dice que el caso de Villalba prueba la ineficacia de las órdenes de alejamiento".

- Datos de la víctima. Se llamaba Mari Carmen Vázquez Cereijo, de 47 años y vecina del barrio de A Guadalupe en Villalba (Lugo). Mujer muerta por arma blanca a manos de su marido/ex pareja. Hallada, a las 12.45 horas, con heridas en el cuello en el garaje familiar de Villalba. No tenía hijos, estaba en trámites de divorcio y ya no residía con el asesino. Había denuncia previa.

- Datos del asesino. Manuel Vázquez, hombre de 50 años que tenía vigente una orden de alejamiento de su ex esposa. En el lugar del suceso apareció ahorcado. Residía desde hace poco tiempo en la aldea de Nete, en el término municipal de Villalba, y desde el sábado se encontraba en paradero desconocido. 
- Causa de la muerte. Heridas de la mujer en el cuello por arma blanca.

- Motivo/Móvil. No se menciona. Sin embargo, se facilita el dato de que el matrimonio estaba en trámites de divorcio y el hombre tenía una orden de alejamiento contra su ex mujer.

- Fuentes. En la primera noticia se cita dos veces que "según fuentes de la investigación" (presuponemos que es la Guardia Civil), aportando datos al caso sobre que pesaba una orden de alejamiento y que los forenses elaboraban un informe para certificar las causas del fallecimiento. También fuentes del Gobierno autonómico, como la Junta de Galicia, expresando su condena y consternación. Además, se recoge la condena que hace el presidente del Gobierno desde Twitter, recordado que la violencia machista "no cesa". En la segunda noticia, se recogen fuentes municipales (declaraciones de la alcaldesa de Villalba) y gubernamentales (del presidente del Parlamento de Galicia), así como un extracto de un manifiesto leído por una persona de Villalba (no se especifica quién ha elaborado el texto) en el que se señala que la manifestación es "un acto de repulsa para denunciar uno de los problemas sociales y estructurales más graves de la sociedad".

Destacan especialmente las críticas que hace a EFE la alcaldesa de Villalba (PSOE) al lamentar el "fracaso de todas las herramientas" previstas en la ley para proteger a las mujeres cuando están en una situación de vulnerabilidad. No olvidemos que la actual Ley Integral de Violencia de Género fue aprobada por el Gobierno socialista en 2004.

- Fotos/Vídeos. La primera noticia se complementa con una foto de la agencia donde aparece la policía local y agentes de la Guardia Civil, en el lugar de los hechos, con un familiar de uno de los fallecidos. En la segunda información hay dos fotos, la primera con una vista general de la masiva concentración ante el Ayuntamiento de Villalba, y en la segunda se ve en primer plano a las autoridades $y$ al fondo personas con camisetas negras con las letras en blanco "Villalba en negro". La fotografía de la tercera noticia muestra a varias mujeres con la camiseta del crespón negro durante la concentración. No hay vídeo.

- Lenguaje. De nuevo en las noticias publicadas sobre este homicidio la expresión mayoritaria para calificarlo es el de violencia machista, aunque también se emplean otras minoritarias como crimen, asesinato y crimen machista. Las palabras mujer y víctima son también frecuentemente repetidas, así como concentración. El presidente del Gobierno, a través de un tuit, lo califica de "machismo criminal" que ha dejado "otra víctima" y acaba escribiendo en su mensaje de la red social: "Tenemos que acabar cuanto antes con esta lacra. Debemos hacerlo juntos y juntas y debemos hacerlo ya". El 
Gobierno gallego expresa su "más enérgica condena" y manifiesta su "consternación" ante el asesinato ocurrido, además de hacer un llamamiento en un comunicado "a toda la sociedad para que se rebele contra esta repudiable lacra". Como vemos, de nuevo, los políticos con responsabilidad directa en esta materia hablan como si el tema no fuera con ellos, implicando a la sociedad, pero sin aportar soluciones al problema. Además, es evidente el abuso institucional de los latiguillos y muletillas que denotan una carencia de recursos dialécticos.

- Utilización de cifras. En la noticia del día 21 se informa en los últimos párrafos que, en lo que va de año, han sido asesinadas 33 mujeres víctimas de violencia machista y que la mujer de Villalba es la número 1.008 desde el año 2003, cuando comenzaron a contabilizarse las mujeres asesinadas a manos de sus parejas o ex parejas.

En la noticia del 22 se difunden los datos leídos en el manifiesto, señalando que Villalba se ha cobrado la primera víctima, la segunda en Galicia y la número 34 en el España en lo que va de año. Pero también aparecen las críticas que, a través del manifiesto, se hace sobre la "frialdad de los números", cifras que "no muestran la verdadera dimensión del drama" que se vive a diario a causa de la violencia machista, porque detrás de esos casos hay "hijas e hijos, hermanas y hermanos, padres y madres, amigos y amigas, compañeras y compañeras":

Lamentablemente, ha llegado el día en el que le ponemos cara a uno de esos fríos números, ya que una de esas mujeres, Mari Carmen, es nuestra vecina, nuestra compañera y nuestra amiga, una mujer con sentimientos, ilusiones y esperanzas, tristemente truncadas, que deja un hueco difícil de llenar.

- Mención a medidas preventivas. Al final de la información del día 21 se indica que las víctimas tienen a su disposición los teléfonos gratuitos 016, 900400 273 y 112 (herramientas de prevención). En la noticia del 23 se divulgan las reivindicaciones de la Plataforma Feminista de Lugo, como son la creación de un juzgado específico de Violencia de Género en Lugo, dado que es la única provincia gallega que aún no cuenta con este servicio. Esta plataforma también reclama más recursos "humanos, económicos y tecnológicos" para "conseguir la necesaria eficacia de las órdenes de alejamiento", y que se ponga en marcha "un programa de formación en materia de género para abogados y jueces".

Nuevamente las manifestaciones de los representantes gubernamentales -en las noticias del 21 y 22-, expresando como mensaje generalista que se debe implicar toda la sociedad, pero sin concretar soluciones ni medios económicos 
para hacerlo. Es el caso del gobierno gallego, del presidente del Gobierno de España y del presidente del Parlamento gallego, que dice este último: "Es un día triste, reflexionemos sobre las cosas que podemos hacer para evitar la violencia machista".

\subsubsection{Asesinato 6. Riet (Rita) Suy (Calpe, Alicante), 22 de julio.}

- Número de noticias publicadas. Un total de 3. Días 22, 23 y 25 de julio.

- Titulares. "Una mujer es asesinada en Calpe por su pareja, que intenta suicidarse", "La Subdelegada: las amistades de la asesinada en Calpe sabían que vivía un infierno" y "Prisión sin fianza para el belga acusado de matar a su pareja en Calpe".

- Datos de la víctima. Mujer belga de 57 años, asesinada por su pareja con un cuchillo. Hechos ocurridos antes de las 1.30 horas en su vivienda de la Urbanización Vallesa, en Calpe. Habían discutido previamente en la calle. Las amistades sabían que sufría continuos maltratos. Tenía una hija. No había denuncia previa. No se indica su nombre en las tres noticias, excepto en el vídeo del día 23 donde se emiten unas declaraciones del delegado del Gobierno en la Comunidad de Valencia en las que alude a Rita.

- Datos del asesino. Pareja de la víctima, también belga y de 61 años de edad. Intentó suicidarse después de la agresión mortal y fue operado en un hospital. El juez decretó su ingreso en prisión provisional. Tiene abierta causa por delito de homicidio. No se facilita el nombre.

- Causa de la muerte. Acuchillada en el tórax.

- Motivo/Móvil. No se menciona, aunque indirectamente en unas declaraciones emitidas en el vídeo que acompaña a la noticia del día 23, el delegado del Gobierno en Valencia señala que este problema "refleja una pérdida de valores culturales y humanistas que repercuten en la parte más débil de la sociedad que son las mujeres"

- Fuentes. En la primera noticia se cita a la Delegación del Gobierno para la Violencia de Género (la cual indica que es la víctima número 34), a la Guardia Civil (aclara que no había denuncia previa), a "fuentes próximas al caso" (fuente indeterminada), a la alcaldesa del municipio (señala que habían discutido previamente en un local de ocio), al presidente del Gobierno (muestra su solidaridad, pero también hace un uso político de este crimen para atacar al adversario), a la Generalidad Valenciana (condena en un Twitter), a la consejera de Igualdad de Valencia (en la red social facilita el nombre de la 
mujer asesinada y califica su muerte de "terrorismo machista"), a la Subdelegación del Gobierno en Alicante y a la Delegación del Gobierno en la Comunidad Valenciana (ambas instituciones convocan un minuto de silencio).

Se observa claramente como una de las fuentes políticas citadas, como son las declaraciones que se recogen de Pedro Sánchez en su discurso de investidura, aprovecha la coyuntura de los crímenes de Villalba y Calpe para rentabilizar su alocución en el Congreso al advertir que "aquellos que quieren banalizar este drama, retroceder al pasado o inventar conspiraciones nos van a tener enfrente".

La noticia del día siguiente muestra los datos ya ofrecidos el día 22, excepto las declaraciones de la subdelegada del Gobierno en Alicante que destaca que la asesinada "estaba en un infierno" y su círculo próximo lo sabía. La noticia del 25 se basa en los datos del Tribunal Superior de Justicia de la Comunidad Valenciana que indican que el juez ha acordado el ingreso en prisión provisional y sin fianza del asesino, y que se le ha trasladado a la cárcel.

El vídeo que acompaña a la noticia del día 23, de 1:59 minutos, está dedicado integramente a las declaraciones del delegado del Gobierno en la Comunidad Valenciana, que no se reflejan en las noticias. Traslada el pésame a la familia, ofrece cifras y a mitad de la emisión del vídeo aporta nuevos datos sobre el caso: el agresor no tenía antecedentes ni en España ni en Bélgica. Llama la atención que un representante institucional divulgue de forma oficial datos recabados de los vecinos -que no suelen ser fiables-, ya que dice: "Según nos cuentan los vecinos, no se les oía que tuvieran ningún tipo de discusión", pero la hija de la asesinada sí corroboró que habían tenido "episodios de discusión subidos de tono".

- Fotos/Vídeos. La noticia del 22 lleva dos fotos (se ven dos cámaras delante del chalet donde residía la víctima y donde se cometió el crimen) y un vídeo de 01:01 minutos, sin voz y con las imágenes exteriores del Hospital Marina Baixa donde ingresaron al asesino. La noticia del 23 incluye tres fotos de la concentración y también incorpora un vídeo con las imágenes de la sede de la Delegación del Gobierno en la Comunidad Valenciana y del delegado, acompañado por cuerpos policiales y personal de la institución. La noticia del 25 va acompañada de una foto (es la misma que se publicó el día 22, por eso pone que es de archivo) con los exteriores de la casa.

- Lenguaje. Las palabras mujer y víctima mortal/víctima son las más repetidas en las noticias sobre este caso, que es denominado mayoritariamente con los conceptos asesinato, asesinato machista y violencia machista. Otras palabras de uso común son pareja, asesinada, número y Guardia Civil. En el relato 
periodístico se utilizan frases hechas como "no consta que hubiera denuncia previa" o "se han decretado dos días de luto oficial".

En cuanto a las manifestaciones político-institucionales, se divulga un nuevo tuit del presidente del Gobierno, utilizando palabras como "abrazo", "solidaridad", "seres queridos" y "drama". La Generalidad de Valencia también hace uso de las redes sociales para transmitir la siguiente frase: "Digamos NO todos juntos a la violencia de género". La consejera de Igualdad y Políticas Inclusivas, también en Twitter, difunde el nombre de la víctima mortal, Rita, y aclara que: "... ha sido asesinada por el terrorismo machista". La alcaldesa de Calpe manifiesta su "repulsa y condena" y traslada su "más sentido pésame". Llama la atención que la subdelegada del Gobierno en Alicante hace uso político del calificativo "insoportable", al igual que lo dijera el día anterior Pedro Sánchez por las redes sociales. Por su parte, el delegado del Gobierno en Valencia, en la comparecencia ante los periodistas, comienza diciendo que "como de costumbre, trasladamos el sentido pésame a la familia". No parece muy acertada esta locución adverbial que, además, pone de manifiesto el abuso de las frases hechas. Emplea "como de costumbre" como si este nuevo asesinato se tratara de un acto protocolario.

- Utilización de cifras. En ninguna de las tres noticias se facilita el nombre de la mujer, se la identifica como la víctima número 34 . En el segundo párrafo de la primera noticia se indica -según datos de la Delegación del Gobierno para la Violencia de Género- que se trata de la "víctima mortal número 1.009 de la violencia machista desde que se empezaron a contabilizar los asesinatos en 2003 y eleva a 34 el número de asesinadas por sus parejas o ex parejas en lo que va de 2019". En la segunda noticia se repiten literalmente los mismos datos en los últimos párrafos, complementados con las declaraciones de la subdelegada del Gobierno en Alicante, considerando que son "cifras insoportables" las 1.009 mujeres asesinadas por violencia machista desde que hay "recuentos oficiales". La tercera noticia no incluye cifras.

El pie de imagen del vídeo del 22 de julio es el siguiente: "La mujer asesinada en Calpe es la víctima 1.009 de la violencia machista". El delegado del Gobierno en Valencia, en sus declaraciones emitidas en el vídeo del 23 de julio, expresa:

...detrás de cada cifra hay casos concretos individuales, pero no es menos preocupante que la suma de todas ellas, 6 casos en lo que va de año en nuestra comunidad y 4 en la provincia de Alicante, pues es una cifra llamativa y muy preocupante. 
- Mención a medidas preventivas. La subdelegada del Gobierno en Alicante pide que se denuncie siempre que se sepa que hay una mujer que sufre maltrato continuo. El delegado del Gobierno en Valencia señala que este problema debe ser tratado en el conjunto de la Unión Europea porque lo sufren los europeos. En el vídeo del 23 de julio aparece durante unos segundos un cartel que figura en la sede estatal donde se ve el 016 de atención a víctimas de malos tratos por violencia de género. Por último, el juez decreta el ingreso en prisión provisional del homicida.

\subsubsection{Asesinato 7. Eva Abad Pérez. Tarrasa (Barcelona), 24 de julio.}

- Número de noticias publicadas. Un total de 2, los días 24 y 26 de julio.

- Titulares. "Un hombre asesina a su pareja en Tarrasa y se entrega a la Policía" y "El juez envía a prisión al hombre que mató a su mujer en Tarrasa y se entregó".

- Datos de la víctima. Eva A.P., de 47 años. Trabajaba en el ambulatorio de la localidad. Fue asesinada por el marido, con arma blanca, en el domicilio familiar situado en el número 2 de la calle Gran Vapor de Tarrasa. Llevaban viviendo juntos ocho años y tenían dos hijos en común, de 12 y 15 años de edad. No constaban denuncias por malos tratos.

- Datos del asesino. Hombre de 50 años, identificado con los iniciales M.P.S., cónyuge de la víctima y de profesión abogado. La mató antes de las 9.40 horas de la mañana. Declarado autor confeso. Tiene causa abierta por delito de homicidio.

- Causa de la muerte. Heridas letales de arma blanca.

- Motivo/Móvil. En la noticia del 24 de julio el alcalde de Tarrasa sugiere que este crimen es "fruto de esta sociedad patriarcal", sin profundizar en motivaciones más concretas.

- Fuentes. De la noticia del 24 se citan fuentes policiales (no se especifican), judiciales (el Tribunal Superior de Justicia de Cataluña confirma que no constaban antecedentes judiciales de violencia) y municipales (el alcalde del municipio condena el "crimen machista" e indica que no había sido atendida por los servicios sociales) y vecinales (informan que la pareja llevaba ocho años viviendo en el piso y que tenían dos hijos menores). La primera fuente señala que el hombre acudió a la comisaría de Policía para entregarse y confesar el crimen. 
EFE también incluye que el alcalde ha decretado tres días de luto, tras presidir la Mesa del Feminicidio en la localidad, y que ha convocado un minuto de silencio frente al edificio consistorial y se prevé una concentración a las 12.00 horas en el centro sanitario donde trabajaba la víctima mortal.

En la noticia del 26 se aportan nuevos datos recogidos de fuentes judiciales (el auto de prisión del juez y el TSJC) y, en los últimos párrafos, se añaden algunos de los ya publicados en la nota de la agencia del día 24 (que es la víctima número 35 , que la mujer no había solicitado ayuda de los servicios sociales del Ayuntamiento de Tarrasa y que no constaban antecedentes judiciales por violencia de género).

La información actualizada se refiere a que el juez de violencia contra la mujer acuerda enviar a prisión al hombre que mató a su esposa. En el auto de prisión se indica que el caso reviste los indicios de un delito de homicidio, si bien no descarta una posterior calificación por asesinato. La nota informativa de la agencia profundiza en los datos del juez que aclaran algo sobre las circunstancias del crimen: fue cometido "con arma blanca, se localizaron huellas y vestigios que hacen inferir la existencia de indicios racionales de criminalidad" y de la participación del acusado en concepto de autor.

Por su parte, el Tribunal Superior de Justicia de Cataluña informa que el detenido está acusado de un delito de homicidio, que se ha acogido a su derecho a no declarar ante el juez y que se ha acordado como medida cautelar una orden de alejamiento respecto de los dos hijos que tenía con la víctima.

- Fotos/Vídeos. La información del día 24 muestra dos fotos y un vídeo. Tanto en la primera como en la segunda fotografía aparecen panorámicas del edificio donde murió la mujer y en el pie de ambas se indica "edificio del número dos del Paseo Gran Vapor de Tarrasa (Barcelona) donde un hombre de 50 años ha matado hoy a su pareja, de 47". La fotografía que documenta la noticia del día 26 es una de las ya publicadas el 24 , en la que se ve el portal del edificio donde se produjo el asesinato y un cámara tomando imágenes. En el vídeo, de 1.20 minutos, se narran los hechos, con un estilo informativo, acompañado de imágenes del lugar, cuya zona está precintada, y aparecen concentrados vecinos, de la comisaría de Policía Nacional donde se entregó el asesino, de la policía autonómica y un coche de la funeraria.

- Lenguaje. En las dos informaciones se incluye la frase habitual referida al homicida: "no le constan denuncias previas por malos tratos". También, al final de la primera noticia, se redacta otra frase común: "El Ayuntamiento ha convocado un minuto de silencio...". Se indica que el alcalde de Tarrasa, después de condenar el asesinato, lo califica de crimen machista. En los textos 
analizados, a diferencia de los anteriores, no prevalecen las declaraciones político-institucionales. Por ello, probablemente, la palabra más utilizada para denominar este suceso sea crimen, seguidas de mujer, pareja, crimen machista, víctima y Policía Nacional. El término violencia machista sólo se emplea una vez, al igual que el de violencia de género.

- Utilización de cifras. Sí, tanto en las dos noticias como en el vídeo. Se observan escasos datos publicados sobre cómo murió la mujer (se señala genéricamente que el cadáver fue encontrado "con signos de violencia" y que fue por arma blanca), sus apellidos (se ofrecen las iniciales), su profesión (sólo se dice que trabajaba en un ambulatorio mientras que en el caso del asesino sí se aclara) o el entorno familiar (madre de dos hijos, sin más). En concreto, en las informaciones de los días 24 (párrafo 5) y 26 (últimos párrafos), así como el final de la emisión del vídeo figura el siguiente texto:

Eva A.P. es la víctima 35 por violencia machista en lo que va de año en España, la cuarta en Cataluña, y la 1.010 desde el 1 de enero de 2003, fecha en la que se inició la contabilidad de mujeres asesinadas por violencia de género.

- Mención a medidas preventivas. La nota de EFE del 26 de julio se hace eco ampliamente del auto de prisión del juez de Violencia de Género, indicando que acuerda el ingreso en prisión sin fianza del autor confeso, ante el riesgo de fuga y de reincidencia contra personas del entorno de la víctima. Respecto de los hijos, se justifica la orden de alejamiento ante la gravedad del crimen, que pone a los dos menores en situación de "víctimas directas", por lo que ambos se erigen "en acreedores de la tutela necesaria y la protección precisa ante el riesgo de cualquier contacto con el investigado y padre de los mismos".

\subsubsection{Asesinato 8. María Jesús Rodríguez (Maruchi). Escalante (Cantabria), 29 de} julio

- Número de noticias publicadas. Dos, el 29 y 30 de julio.

- Titulares. "Hallada una mujer asesinada en su domicilio al notificarle la muerte de su marido en un accidente" y "El matrimonio muerto de Escalante (Cantabria) tenía dos hijos mayores".

- Datos de la víctima. Mujer de 52 años, identificada con las iniciales M.J.R.R., murió apuñalada por su marido el lunes 29. Tenía dos hijos mayores y había sido abuela recientemente. Residente en Zaragoza, aunque desde hace dos años vivía en el Barrio San Roque de Escalante. No constaban denuncias previas por malos tratos. 
- Datos del asesino. Juan A.E., esposo de la víctima. Falleció en un accidente de tráfico, presentando heridas de arma blanca. En la noticia no se especifica si se trata de un crimen de violencia de género, pero sí se aclara que se está investigando.

- Causa de la muerte. Apuñalamiento.

- Motivo/Móvil. No se menciona. El delegado del Gobierno en Cantabria dice, en las declaraciones emitidas en el vídeo del 30 de julio, que se desconocen las causas y que es un tema que forma parte de la investigación. Además, el juzgado decreta el secreto de sumario.

- Fuentes. En la información se cita a la Delegación del Gobierno en Cantabria (aporta datos sobre la edad de la víctima, sus iniciales y que no constaban denuncias). También otra fuente institucional como es el alcalde del pueblo, haciendo comentarios sobre que "es un pueblo tranquilo", que ha sido "un shock tremendo" o que el matrimonio estaba "muy integrado" en el municipio. En el vídeo se incluyen nuevamente las citadas fuentes, ampliando sus declaraciones institucionales. Por una parte, las del alcalde (vuelve a recalcar que era una "pareja integrada en el pueblo") y las del delegado del Gobierno en Cantabria ("...apunta a un suceso interno en el matrimonio. Se investiga y no se sabe si es violencia doméstica o violencia de género").

- Fotos/Vídeos. Cuatro fotografías (dos con vistas de la casa de la mujer, una con la imagen de un Guardia Civil frente a la casa de la asesinada y otra del lugar del accidente de tráfico) y un vídeo que completa la noticia del 30 de julio (de 1:47 minutos donde una voz en off informa del suceso, destacando que se están investigando los hechos y las imágenes exteriores de la casa de la víctima y del alcalde de Escalante y del delegado del Gobierno en Cantabria haciendo declaraciones).

- Lenguaje. En las dos noticias publicadas por EFE se hace mención a un "posible caso de violencia machista". También se señala en ambas informaciones la frase referida a que la víctima "no había presentado denuncias previas por malos tratos". La palabra marido es una de las más repetidas (se le señala informativamente como presunto asesino), junto a mujer, muerte, pareja y denuncias. "Estaban muy integrados" es la expresión del alcalde a referirse al matrimonio.

- Utilización de cifras. No se ofrecen cifras porque en la información de agencia del 30 de julio aún no se había confirmado que fuera un asesinato de violencia de género. La Delegación del Gobierno para la Violencia de Género ratificó a 
los medios el 31 de julio que era un asesinato machista, ya que el marido acuchilló a la cónyuge y luego se suicidó estrellándose con su coche.

- Mención a medidas preventivas. No se mencionan.

3.1.9. Asesinato 9. María Josefa (Pepi) Santos. Villagonzalo Pedernales (Burgos), 31 de julio.

- Número de noticias publicadas. Una, día 31 de julio.

- Titulares. "Un hombre mata a su mujer, hiere a su hijo y se suicida con una escopeta".

- Datos de la víctima. Mujer de 55 años asesinada por el marido, en el domicilio familiar. Era cuidadora del comedor escolar del municipio burgalés. Tenía dos hijos mayores, uno de ellos de 29 años ha resultado herido. No había puesto denuncia. No se facilita el nombre de la víctima, ni tampoco sus iniciales.

- Datos del asesino. Hombre de 55 años, cónyuge de la víctima mortal. Después de cometer el crimen se suicidó con su escopeta. Trabajaba como empleado de banca y se prejubilaba el mismo día que ocurrieron los sucesos violentos. Era cazador y tenía licencia de armas en regla. No se divulga el nombre del agresor, ni sus iniciales.

- Causa de la muerte. Tiros de escopeta.

- Motivo/Móvil. No se menciona.

- Fuentes. Dos fuentes institucionales: el subdelegado del Gobierno en Burgos y la alcaldesa de Villagonzalo Pedernales. El primero aclara que se trata de un caso de violencia machista, que el hijo tiene afectada la médula y está siendo operado y que no constaban denuncias. No aporta datos sobre la mujer. La alcaldesa sí habla sobre la fallecida, señalando que era muy querida en el pueblo al ser la cuidadora del comedor escolar de este municipio. También se recoge que la regidora decretará tres días de luto en la localidad y convocará una concentración de condena.

- Fotos/Vídeos. Tres fotografías ilustran gráficamente la noticia, en la primera se observa al fondo la camilla de la mujer asesinada que se introduce en la ambulancia. Las dos primeras imágenes, en las que se ve un vehículo del Instituto de Medicina Legal junto a la casa de la víctima, llevan el mismo pie de foto: 
Agentes de la Guardia Civil acuden este miércoles a un domicilio de Villagonzalo Pedernales, en el alfoz de Burgos, donde un hombre ha disparado y matado a su pareja, de 55 años, y se ha suicidado posteriormente también de un tiro. Un hijo del matrimonio, de 29 años, se encuentra grave, herido por arma de fuego.

La tercera imagen muestra la concentración en repulsa por el asesinato.

- Utilización de cifras. En los dos últimos párrafos de la noticia se hace mención a los siguientes datos estadísticos:

Tras el asesinato cometido en esta población burgalesa, el número de víctimas de la violencia machista se ha elevado a 37 en lo que va de año en España. Otro caso más se encuentra en investigación. Desde 2003, año en el que comenzaron a contabilizarse de manera oficial las víctimas de violencia machista, han sido 1.012 las mujeres muertas por esa causa.

- Lenguaje. El término violencia machista es el más utilizado para calificar este nuevo asesinato. Mujer, víctima y matrimonio son las dos palabras más repetidas. En el desarrollo de la noticia se incluyen las frases habituales de: "...no consta que existieran antecedentes ni denuncias" y "La alcaldesa decretará tres días de luto en la localidad". En cuanto a la terminología políticoinstitucional que se refleja en las noticias, se indica que "El subdelegado de Burgos ha enmarcado los hechos en un caso de violencia machista".

- Mención a medidas preventivas. No aparecen.

\section{CONCLUSIONES}

\subsection{Número de noticias publicadas}

De los 9 asesinatos cometidos durante el mes de julio, la agencia EFE publica en su página web 21 noticias. Por tanto, hay una media de 2,3 informaciones divulgadas por cada uno de estos crímenes de violencia de género.

\subsection{Sección}

Van todas en Edición España / Sociedad.

\subsection{Titulares}

Los 21 títulos de las noticias incluyen el antetítulo en mayúscula 'Violencia machista', a modo de cintillo. No se utilizan los subtítulos, como es común en las informaciones de agencias. En todas las noticias analizadas se trata de títulos informativos, resaltando 
el hecho de la comisión de los asesinatos hacia las mujeres. A modo de ejemplo, las primeras noticias que se publican sobre cada uno de los crímenes llevan los siguientes titulares: "Mata a su mujer...", "Asesinada una mujer...", "Un hombre mata a su mujer...", "Un hombre mata a su ex pareja...", "Una mujer es asesinada...", "Un hombre asesina a su pareja", "Hallada una mujer asesinada en su domicilio..." y "Un hombre mata a su mujer...". Hay una sola excepción, ya que, aunque se titula con estilo informativo, se enfoca el suceso como una mera cifra estadística: "La mujer hallada muerta en Málaga es la víctima 1007 de violencia machista".

En las segundas noticias difundidas los titulares se centran mayoritariamente en la detención o el ingreso en prisión de los autores, excepto dos que resaltan las concentraciones ciudadanas de repulsa. Sólo uno de los títulos publicados aclara cómo se produjo la muerte violenta de las mujeres, en este caso es el referido: "La mujer asesinada en Rute sufrió un traumatismo severo en la cabeza". Hay que destacar que los titulares de la agencia son informativos y no incurren en el sensacionalismo.

Los pies de fotos son todos informativos, así como los pies de imagen de los vídeos. Sólo en uno de ellos se titula, destacando la cifra: "La mujer asesinada en Calpe es la víctima 1.009 de la violencia machista".

\subsection{Datos de la víctima}

En todas las noticias analizadas sobre los nueve casos, publicadas después de la comisión de los asesinatos, se indican las edades de las mujeres y las causas de las muertes violentas. Sin embargo, en más del $55 \%$ del total de noticias no se facilita el nombre de las víctimas. Así, en los contenidos informativos sobre los cinco asesinatos de Elche, Cortes de la Frontera, Calpe, Escalante y Villagonzalo Pedernales no se reflejan los nombres de las mujeres (sólo se dice que se trata de una mujer asesinada de "X" años, excepto en el caso de Escalante donde figuran las iniciales, M.J.R.R.), mientras que en los cuatro restantes (Rute, Sala de los Infantes, Villalba y Tarrasa) sí se le pone nombre a la mujer. Sólo en el asesinato de Villalba se da a conocer el nombre completo de la fallecida: María del Carmen Vázquez Cereijo. En los demás casos, excepto en el de Rute donde se publica que se trata de Piedad Cruz, se las identifica como Mónica A.A. (Sala de los Infantes) y Eva A.P. (Tarrasa).

Este tratamiento contribuye a la invisibilidad de estas mujeres, que se convierten en meros números estadísticos y no en personas individuales. El hecho está motivado en parte porque la Delegación de Gobierno para la Violencia de Género no facilita los nombres de las asesinadas y otras fuentes oficiales que suministran los datos no suelen hacer públicos los nombres de las víctimas, con lo cual a nivel institucional también se favorece que estos homicidios sean tratados como frías cifras. 
Nos encontramos que EFE publica mayoritariamente el dato referido a la edad, pero no el nombre de la asesinada, que es más importante para identificar a la persona. La causa de la muerte es también otro de los datos de mayor prevalencia en los contenidos informativos analizados, junto al hecho de si la mujer había denunciado o no por maltrato (de los nueve asesinatos analizados sólo en uno de ellos la mujer denunció, como es el caso de Villalba). También es habitual que se publique si convivía o no con su pareja y si tenía hijos. En este sentido, de las nueve mujeres fallecidas, sólo dos estaban separadas, el resto convivía con sus parejas. Eran madres siete de las nueve asesinadas.

Otro dato significativo es que de las 21 noticias publicadas sólo en dos se indica la profesión de la víctima. Se trata de las mujeres asesinadas en Tarrasa y Villagonzalo Pedernales, donde la agencia aclara que la primera "trabajaba en el ambulatorio de la localidad" (no se especifica que era médica) y la segunda era cuidadora del comedor escolar. Es decir, en menos del $10 \%$ de las informaciones se facilita este relevante apunte de carácter laboral, lo cual es indicativo de la escasez de referencias a la persona que apenas se divulgan.

Al igual que ocurre con los datos de los agresores, no se reseña la nacionalidad, ya que los protagonistas de estos sucesos suelen ser del lugar donde se han cometido los delitos. Sólo cuando la víctima o el autor son de nacionalidad extranjera, se informa sobre su procedencia, como son los casos de Sala de los Infantes (búlgaros) y de Calpe (belgas).

\subsection{Datos del asesino}

De los nueve asesinatos divulgados por EFE, sólo en tres aparece el nombre de los autores, como son los casos de Rute (Juan R.G.), Villalba (Manuel Vázquez) y Escalante (Juan A.E.). En más del $66 \%$ del total de las informaciones no se cita el nombre y apellidos del asesino. Como comprobamos, se divulgan porcentualmente menos los nombres de los asesinos que de las asesinadas. Además, de los hombres aparecen sus nombres incompletos, lo cual no facilita su identificación. No obstante, sí se hacen públicos datos sobre sus edades y relación que tenían con las mujeres (pareja, ex pareja o marido). En el caso de que los agresores tuvieran hijos comunes con las víctimas mortales, siempre se indica.

Con respecto a otros datos personales como la profesión, no es habitual que se publiquen, ya que sólo en las noticias sobre los asesinatos de Cortes de la Frontera, Tarrasa y Villagonzalo de Pedernales se aclaran que eran militar retirado, abogado y empleado de banca, respectivamente. Cuando los agresores se han declarado autores confesos, sí se refleja en las noticias. Si se suicidan también queda anotado informativamente (del total de los nueve asesinos, cuatro se quitaron la vida en julio). La agencia EFE ha informado, prácticamente en casi todos los casos, sobre los delitos 
que se les imputan a los hombres en las causas judiciales abiertas que suelen ser el genérico de homicidio, excepto en el caso de Elche que es específico de asesinato.

Como hemos comprobado, de los nueve asesinos, cuatro se declararon autores confesos, otros cuatro se suicidaron y uno intentó suicidarse (tentativa). En estos casos sí se podría haber identificado a todos los homicidas, facilitado nombre, apellidos y fotos. Las recomendaciones deontológicas y legales aconsejan que los medios no los identifiquen hasta que exista sentencia condenatoria -debido a la presunción de inocencia-, excepto si concurren las circunstancias que hemos indicado anteriormente.

\subsection{Causas de la muerte}

Este dato siempre se recoge en las primeras noticias publicadas después de que se cometan los asesinatos. En los nueve asesinatos perpetrados las causas que ha recogido la agencia han sido: martillazos (1 caso: Rute), apuñaladas o acuchilladas por arma blanca (6 casos: Sala de los Infantes, Elche, Villalba, Calpe, Tarrasa y Escalante) y a tiros por rifle o escopeta (2 casos: Cortes de la Frontera y Villagonzalo Pedernales). Como vemos, la causa mayoritaria son las heridas mortales de arma blanca.

\subsection{Motivo / Móvil}

En ninguna de las noticias analizadas se señalan los motivos por los que los maridos, parejas o ex parejas han asesinado a las mujeres. No se explican en las informaciones publicadas por EFE cuál es móvil que les impulsó a cometer estos crímenes.

Aunque no se menciona directamente, en las noticias sobre los asesinatos de María Asunción, en Elche; y María del Carmen Vázquez Cereijo, en Villablanca, se deja traslucir que sus muertes pudieron estar motivadas como consecuencia de sus recientes separaciones o trámites de divorcio. Por su parte, en el homicidio de Monika Asenova, en Sala de los Infantes, se informa que había antecedentes de violencia de género y que actualmente sufría maltrato habitual en el hogar, hechos que pudieron motivar el desenlace final. En la agresión mortal de María Jesús Rodríguez, en Escalante, en el vídeo que complementa a la noticia del 30 de julio el delegado del Gobierno en Cantabria manifiesta a los periodistas que se desconocen los motivos y que "eso forma parte de la investigación".

En otras noticias y vídeos se matiza que los juzgados han decretado secreto de sumario, lo cual impide obtener más datos al respecto, al menos por la vía oficial. En cualquier caso, pese a la complejidad en la obtención de información sobre esta variable, entendemos que los medios podrían esforzarse más para acceder a otras fuentes especializadas y del entorno familiar o policial (contacto no oficial), al objeto de 
conseguir más información y no centrarse únicamente en las declaraciones institucionales. No hay que olvidar que se está informando sobre de la vida de una persona, en este caso de mujeres que acaban de ser asesinadas por sus compañeros sentimentales o ex parejas. Lo conveniente sería que los medios hicieran una reflexión sobre por qué ocurre esto y qué hay detrás de cada crimen de género.

\subsection{Fuentes}

EFE ha utilizado 88 fuentes para cubrir informativamente estos asesinatos. Del total de las 48 fuentes textuales que documentan las noticias publicadas sobre los nueve asesinatos, un $85,42 \%$ son oficiales y el $14,58 \%$ restante no oficiales. Las informaciones que ha difundido sobre violencia contra la mujer con resultado de muerte se han basado mayoritariamente en declaraciones político-institucionales (gobierno central, municipal y local, respectivamente) y de forma mucho más minoritaria en fuentes judiciales y policiales. En cuanto a las fuentes no oficiales, las más frecuentes son las indeterminadas policiales (son anónimas, contactos internos no identificados, provenientes de las investigaciones llevadas a cabo por la Guardia Civil, ya que prácticamente todos los asesinatos se han producido en pueblos españoles, excepto en los casos de Elche y Tarrasa), seguidas por las vecinales. Por tanto, el tratamiento periodístico está muy condicionado e influenciado por los discursos políticos, lo que resta objetividad, calidad y uniformiza el mensaje que llega a los ciudadanos.

Con respecto a las fuentes audiovisuales (un total de 40), son más numerosas las fotografías que los vídeos, siendo casi todas de EFE. Las textuales prevalecen en un $54,54 \%$ frente a las audiovisuales que suponen un $45,54 \%$, lo que resalta la importancia de esta última fuente como complemento del texto periodístico principal.

También hemos detectado que en alguno de los casos estudiados -como el de Sala de los Infantes y el de Escalante- los mensajes que se transmiten por diversas fuentes son confusos e incluso contradictorios. Por ejemplo, cuando en una primera noticia se informa de fuentes vecinales que "la pareja estaba perfectamente integrada", pero en la información del día siguiente el subdelegado del Gobierno aclara que habían existido episodios anteriores de violencia de género y que la mujer sufría habitualmente maltrato. $O$ si se indica en la misma noticia que fuentes municipales apuntan que "el matrimonio estaba muy integrado en el municipio", y a continuación otra fuente gubernamental deja abierta la posibilidad de que existiera violencia doméstica previa. Entendemos que difundir estas suposiciones o consideraciones subjetivas nada aportan informativamente, sólo sirven de relleno y deberían de obviarse en aras a la calidad informativa del mensaje que se transmite a la sociedad.

En cualquier caso, hacemos una crítica genérica a los medios de comunicación, en particular a EFE, por no indagar y acceder a otras fuentes que proporcionen los 
nombres e imágenes de las víctimas mortales con la finalidad de darles identidad y humanidad y que no aparezcan sólo como un número. Aclaramos, no obstante, que en ocasiones será conveniente el consentimiento de los familiares de la víctima, porque nos podemos encontrar con su inicial negativa para que no aparezcan datos personales de la mujer asesinada. Además, se pone en evidencia la escasez de fuentes expertas -profesionales de la psicología, criminología, personal técnico y directivo que trabaja en asociaciones de mujeres maltratadas, abogados especializados en violencia de género y del ámbito policial- a la hora de tratar estas informaciones que servirían para complementar y dar una visión más rigurosa.

\subsection{Fotos / Vídeos}

En total se han publicado 32 fotografías y 8 vídeos. Las imágenes que complementan las noticias aportan información adicional para situar y localizar los hechos. Como ya hemos mencionado, las fuentes audiovisuales tienen gran relevancia y muestran de forma mayoritaria los lugares donde han ocurrido los asesinatos. Dan a conocer el escenario del crimen o la ubicación donde se ha cometido el delito. Las imágenes difundidas por EFE enseñan las vistas exteriores de las casas o de las entradas a los pisos donde vivían las víctimas mortales, en las que se pueden ver en los alrededores a policías, vecinos, cámaras de televisión y fotógrafos. Sirven para documentar gráficamente las primeras noticias que se publican después de estos sucesos.

En las segundas noticias difundidas sobre estos homicidios las reproducciones más frecuentes son las relativas a concentraciones de protesta por los asesinatos, en las que aparecen representantes gubernamentales, municipales y vecinos. Es muy poco común que se plasme visualmente el momento en que la mujer asesinada es introducida en una camilla en la ambulancia del Instituto de Medicina Legal. Ocurre sólo en dos casos: en la tercera foto que ilustra la primera noticia del crimen de Rute, bajo el pie de foto "Agentes de la Guardia Civil despliegan una lona para tapar el traslado del cuerpo sin vida de la mujer de 42 años asesinada presuntamente por su marido en su vivienda de la localidad cordobesa de Rute"; y en la primera fotografía de la noticia sobre el asesinato de la mujer de Villagonzalo Pedernales, donde se observa al agente de la Guardia Civil y a personal del Instituto de Medicina Legal portando la camilla de la asesinada para introducirla en la ambulancia.

Ninguna de las fotografías y los vídeos publicados por la agencia ofrecen imágenes de las víctimas y los autores. Sólo hay una excepción: el asesinato de Piedad Cruz en Rute es el único donde aparece el homicida, aunque sale de espaldas y apenas se le puede reconocer el rostro cuando entra en el coche policial.

Sorprende la frecuencia con la que se sacan las imágenes de los políticos, pero nulas las de los protagonistas de estos hechos. La difusión de las imágenes de archivo de las víctimas serviría para ponerles cara y que no se convirtieran en un frío número 
oficial. Por su parte, el dar visibilidad a los homicidas también sería mucho más aconsejable en EFE y otros medios como la televisión -ya que en la mayoría de los casos se trata de autores confesos-, dado el interés social que despiertan y como correctivo social y preventivo de nuevas agresiones ${ }^{3}$. Los pies de foto son todos informativos y guardan relación directa con la imagen que se ofrece. Sólo se observa una excepción en el píe de imagen de un vídeo que titula haciendo mención a que se trata de la víctima 1.009.

Referente a la autoría de las fotografías van todas firmadas, salvo una de archivo con la imagen del político Pedro Sánchez. Las imágenes de los vídeos son también autoría de la agencia estatal, excepto en el primero de los emitidos sobre el asesinato de Piedad Cruz, donde una de las imágenes que se ofrecen de la detención del autor confeso fueron facilitadas por la Policía Nacional.

\subsection{Lenguaje}

En los titulares de las noticias analizadas el sustantivo más utilizado es mujer, el verbo más empleado es matar y con respecto al adjetivo es asesinada. La denominación más frecuente para estos casos es el de crimen machista. En los pies de fotos y de imagen de vídeos la palabra más comúnmente usada es mujer, seguida de hombre, mata, asesinada y pareja. También, aunque con menor frecuencia, la acepción Guardia Civil, violencia machista y concentración, así como la expresión "nuevo caso de violencia machista". En cuanto al desarrollo del texto en las noticias la expresión más empleada es la de violencia machista, seguida de crimen machista y, minoritariamente, asesinato machista.

Además, todas las informaciones van encabezadas con "violencia machista". En conjunto, la agencia EFE hace uso mayoritario de "violencia machista" para calificar estos asesinatos. Las palabras más repetidas son mujer, hombre, víctima, pareja, denuncia, Guardia Civil, asesinada, asesinato y crimen. Con respecto a la común utilización del vocablo hombre para referirse a la persona del sexo masculino que ha matado a una mujer, se advierte por contra una escasez de términos como homicida, asesino, criminal o delincuente. En estos casos analizados se trata, además, de autores confesos o que se han suicidado, por lo que estimamos pertinente el empleo de dichas adjetivaciones.

...el agresor debe ser identificado claramente, si no con su identidad, dadas las cautelas judiciales, sí en cuanto a su comportamiento, su forma de vida o sus antecedentes penales (caso de tenerlos). Tampoco se debe minimizar en los medios los actos delictivos cometidos por los autores de un asesinato, utilizando expresiones eufemísticas como el agresor o el maltratador; en realidad son delincuentes, homicidas, asesinos, criminales (Rodríguez, 2008, p. 185). 
La mayoría de las noticias y los vídeos emplean frases similares en su redacción o locución que uniformizan la información, convirtiéndola en un formulario del tipo: "Es la víctima mortal número 'mil y pico' de la violencia machista, desde que se empezaron a contabilizar en 2003, y eleva a 'X' el número de asesinadas en 2019". Es también usual en los textos indicar si la víctima había puesto, o no, denuncia por malos tratos.

La terminología político-institucional más habitual que se recoge en las noticias de la agencia es la referida a la condena del asesinato ("repulsa y condena", "enérgica condena" y "condena firme"). También es recurrente el sustantivo "lacra" que literalmente significa, según la Real Academia de la Lengua, "secuela o señal de una enfermedad o achaque". Otras expresiones repetidas políticamente son "solidaridad", "repugnancia" e "indignación". La denominación que los políticos utilizan mayoritariamente para referirse a este tipo de criminalidad de género es "violencia machista", seguida de "crimen machista". Por tanto, políticos y periodistas coinciden en usar "violencia machista" cuando se refieren a este tipo de asesinatos.

En las declaraciones mediáticas de los representantes gubernamentales se observa un abuso del plural, recurso lingüístico para diluir la responsabilidad política y socializar el problema. Se utilizan más las proclamas políticas en detrimento de un lenguaje más directo con aportación de datos técnicos y anuncios de actuaciones y medidas preventivas, de protección y punitivas.

\subsection{Utilización de cifras}

Se utilizan cifras de la Delegación del Gobierno para la Violencia de Género en el $71,42 \%$ de las informaciones publicadas. Ahora bien, hay que aclarar que, en las dos noticias de EFE sobre el asesinato de María Jesús Rodríguez, en Escalante, no se incluyeron datos numéricos porque todavía no se había confirmado oficialmente que se trataba de un nuevo asesinato de género. De haberse corroborado, este porcentaje sería aún más elevado. También se ha contabilizado que, del total de vídeos emitidos, en un $75 \%$ de los casos se hace mención a estas cifras oficiales.

La mayoría de las informaciones se divulgan con el texto siguiente: "La Delegación del Gobierno para la Violencia de Género ha confirmado que la mujer asesinada es la víctima número ' $X$ ' de este año y la mil y pico desde que comenzaron a registrarse las estadísticas en 2003". Estos datos se suelen colocar en el desarrollo final tanto de las noticias como de la emisión de los vídeos. También es común especificar que determinado asesinato es el número ' $X$ ' en la provincia de que se trate y el ' $Y$ ' en la comunidad autónoma donde haya acontecido.

La cifra que más se resalta en todas las noticias y textos audiovisuales consultados es el número total de víctimas mortales. Ejemplo: "Con este nuevo caso de violencia machista son ya 'mil y pico' las mujeres asesinadas desde 2003". Como vemos, 
interesa más destacar el nuevo caso que la persona en sí que acaba de ser asesinada, la cual se convierte en un dato cuantitativo oficial.

\subsection{Mención a medidas preventivas}

De los nueve casos de asesinatos estudiados sólo en los dos últimos (Escalante y Villagonzalo Pedernales) no se mencionan en las noticias medidas de prevención. Ello tiene su reflejo informativo, ya que de las 21 noticias analizadas en 10 se señala este tipo de datos y de los 8 vídeos visionados en uno también se constata. Por tanto, en el $47,61 \%$ de las informaciones textuales publicadas por EFE se difunden estas medidas. En el caso de las informaciones audiovisuales es muy minoritaria la inclusión de estos datos.

Con respecto al tipo de medidas que con mayor frecuencia se incluyen están, por este orden, los recordatorios a los teléfonos 016 (de atención a las víctimas) y 112 (para ciudadanos que sean testigos de agresiones), los ingresos en prisión provisional y sin fianza (ante el riesgo de fuga y de reincidencia del homicida con personas del entorno de la víctima mortal), la implicación de la sociedad a través de denuncias (en el caso de ciudadanos que sean testigos o conocedores de maltrato en su entorno), las órdenes de alejamiento de los hijos menores y retirada de la patria potestad (por ser consideradas víctimas directas) y otros recursos (creación de Juzgados de Violencia sobre la Mujer, más medios humanos y económicos y programas formativos).

\section{PROPUESTAS PARA MEJORAR EL TRATAMIENTO EN LOS MEDIOS}

Recogemos en este apartado diversas opiniones de periodistas, abogados y asociaciones profesionales y entidades especializadas en la materia, así como los testimonios de familiares de las víctimas.

\subsection{Asociación de Periodistas Gallegas}

Considera que, a la hora de informar sobre esta temática, se debería prescindir de las fuentes vecinales, sobre todo de los vecinos que no tienen ninguna relación con la víctima porque se puede caer en el dramatismo y el morbo. Destaca que la redacción de estas noticias de violencia machista "parece un formulario". Es como rellenar una serie de preguntas en las que se pone o no el nombre de la víctima, circunstancias en la que fue asesinada, cuántas mujeres han muerto a lo largo del año en España, si había puesto denuncia o no y si tenía protección.

La APG señala que se repite una y otra vez en las noticias si la víctima puso denuncia o no. Lo importante es que "a veces parece que se culpabiliza" a la mujer porque no interpuso una denuncia. 
Punto y final. Esto es de lo que se suele informar. Nos parece una cuestión irrelevante cuando se informa de si la víctima puso denuncia o no, si tenía una orden de protección o no. A veces parece que se culpabiliza a la víctima porque no interpuso una denuncia. Esto habría que tratarlo de otra manera y contextualizarlo, diciendo que esa mujer no ha denunciado porque no sabía qué recursos podía usar o porque tenía miedo. Es un poco de sentido común el tener la responsabilidad y estar concienciado de este problema (2019).

Otra aportación no menos importante que hace esta asociación profesional se refiere a que los medios, debido a la precariedad laboral en la que se encuentran, no reflexionan y van a lo más rápido, puesto que "es más fácil sacar unos totales o declaraciones al vecino del $5^{\circ}$ que entrevistar a un experto que explique por qué ocurre esto o por qué falla el sistema".

\subsection{Unión de Periodistas Valencianos}

Con respecto a poner el nombre y apellidos de la víctima mortal, esta asociación profesional aclara que, dentro del movimiento feminista, hay opiniones que piden la visibilización de las mujeres víctimas, dando a conocer sus nombres para que no queden en una mera cifra y para mantenerlas en la memoria. En cuanto a los agresores, "siempre habrá que señalar, si procede, su condición de presunto (investigado), si lo es, mientras no haya sentencia". Con respecto a identificarlo con nombre y apellidos, es una práctica considerada favorablemente en el ámbito feminista y el policial, "entre otras razones porque puede permitir evitar nuevas agresiones o proteger a otras posibles víctimas".

Parte del movimiento feminista es favorable a que se conozcan los nombres y la imagen de los agresores y que esta información sea pública y fácilmente accesible, así como la relación de condenados por agresiones machistas. Las mismas mujeres sobrevivientes solicitan que la lista de condenados, accesible para la policía y para el sistema judicial, sea pública por seguridad de las mujeres y por interés público (2018).

\subsection{Consejo Audiovisual de Andalucía}

Recomienda que no se banalice la información, evitando la rutina periodística y los mensajes que pueden insensibilizar a la sociedad. También recalca que hay que contextualizar cada uno de estos casos en el problema de la violencia de género y poner de manifiesto que no se tratan de hechos aislados. Eso no se consigue aportando sólo datos estadísticos, sino humanizando a la víctima asesinada y realzando la figura de los menores como víctimas directas de la violencia de género. 
Especialmente en los titulares: "Un nuevo caso de violencia de género", "una víctima más...". Las víctimas no mueren, las matan. No son responsables por el hecho de no haber denunciado o reanudado una relación (2016).

\subsection{Redactora de El Progreso de Lugo. Cristina Pérez Rodríguez ${ }^{4}$}

La periodista señala que la información local, por su proximidad, permite informar de una forma más cercana sobre la fallecida. La gente identifica a la mujer asesinada, con su nombre y apellido. Pero en los medios de ámbito nacional, sobre todo en la televisión, "interesa más el caso que la persona". Es un trato informativo más frío y la víctima mortal se convierte en una cifra. El periodismo local, indica, posibilita un mayor conocimiento del entorno y los hechos. En cuanto al uso de las fuentes, en materia de violencia de género, es una información "sensible y difícil de tratar".

En el caso de los crímenes, intentamos obtener datos del 112 o del Tribunal Superior de Justicia de Galicia (suele ser nota institucional). El informe oficial es el que te cuenta la Guardia Civil o la Policía. Las fuentes vecinales no suelen ser fiables. Las fuentes familiares son más fáciles de conseguir en la información local, aunque su tratamiento depende de cómo trabaje el periodista y se atenga a respetar, o no, algunos límites que pone la familia. La información local es más próxima y se trabaja con el periodismo de investigación, acudiendo al lugar de los hechos. Por ejemplo, el caso del asesinato de Villalba fue la gran noticia local del diario, tuvo gran protagonismo y se redactó con mayor profundidad (2019).

\subsection{Familiares cercanos de la mujer asesinada María del Carmen Vázquez (Villalba)}

Critican que, a la hora de abordar estos casos en las televisiones, son demasiadas escuetas las informaciones que se emiten, especialmente sobre este crimen. Señalan que no son partidarios de utilizar fuentes vecinales, ya que "delante de los medios de comunicación se dice una cosa, pero por detrás la versión cambia por completo". Consideran que realmente se puede saber la verdadera versión "cuando se habla detrás de las cámaras". Dichas fuentes provocan que "la realidad de los hechos sea tergiversada". También reconocen que en este asesinato la familia sabía que la víctima sufría violencia de género, pero no intervinieron por miedo y porque no imaginaron que pudiera ocurrir ese trágico desenlace. A modo de conclusión, entendemos que esta fuente familiar entrevistada quiere manifestar que, como medida preventiva, la sociedad y los medios de comunicación deberían dar más voz al sufrimiento callado de muchas mujeres que conviven con sus futuros asesinos. 


\subsection{Fundación Mujeres ${ }^{5}$}

Con respecto al tratamiento informativo sobre las mujeres asesinadas por violencia de género, establece que "es un tema complicado". Para esta organización feminista el facilitar las cifras es importante, "pero no siempre es bueno dar información sobre la fallecida porque estamos comprobando que afecta a los niños que se quedan huérfanos y tienen que seguir su vida". En cuanto a ofrecer datos del homicida, entienden que se suele proteger su identidad y que "tenemos que pensar que los huérfanos sufren un doble estigma; son hijos de un asesino que ha matado a su madre y esta doble condición provoca situaciones difíciles en el día a día".

\subsection{Aida Escudero García. Abogada especializada en violencia de género}

Indica que los medios de comunicación deberían difundir asiduamente otros supuestos de violencia de género, que apenas tienen repercusión porque son menos llamativos que los asesinatos y, sin embargo, se producen con más frecuencia. Ello favorecería la prevención.

La gente simplifica y considera que violencia de género es que maten a las mujeres y eso es el último paso de la cadena. Es importante que los medios y la sociedad conozcan todos los supuestos de la violencia para que aprendan a detectarla y prevenirla, reconociendo conductas de maltrato. La mayoría de las mujeres no son conscientes de que las están maltratando, ya que siempre empieza de forma psicológica y sutil (2019).

\subsection{Beatriz Martínez Rodríguez. Profesora de la Universidad de Vigo}

Manifiesta que es importante poner circunstancias a las víctimas, "por una cuestión de humanidad, y para luchar a fin de que no se repitan estos sucesos en el futuro". Aunque, reconoce, que esta opinión no es compartida por todos los protocolos contra la violencia de género, puesto que "hay una doble línea, entre los que proponen dar el mayor número de datos posible para visibilizar la violencia, y los que lo consideran una concesión al morbo y proponen limitar al máximo los detalles concretos" (2011: 167).

\section{Notas}

1 Es una sociedad mercantil, cuya titularidad corresponde a la Sociedad Estatal de Participaciones Industriales (SEPI) de España. Según recoge en su página web, es la primera agencia de noticias en español y la cuarta del mundo.

${ }^{2}$ La serie 'La vida de las víctimas', promovida por este diario digital de ámbito nacional, publica reportajes que cuentan las circunstancias que han llevado a la muerte violenta de numerosas mujeres por parte de sus maridos o ex parejas en España desde el año 2017. Es un tratamiento periodístico donde se profundiza caso por caso las situaciones que vivieron estas 
mujeres hasta que fueron asesinadas. Se incluyen sus fotos y nombres para contribuir a visualizar esta dramática realidad y favorecer que cada caso no sea tratado como una fría cifra oficial. Recibió en 2018 el Premio Menina 2018, concedido por la Delegación del Gobierno en Andalucía, en reconocimiento a la labor periodística de contar las historias de estas mujeres y como forma de luchar contra este tipo de crímenes.

${ }^{3}$ Los periódicos de tirada nacional suelen publicar la foto facilitada por EFE. Sin embargo, en los diarios locales del lugar donde ocurre el suceso pasa lo contrario. Ponemos como ejemplo el asesinato de la mujer de Villalba (María del Carmen Vázquez Cereijo), donde periódicos como El Progreso de Lugo o La Voz de Galicia publicaron una foto de archivo de la víctima. Ello es debido tanto a la cercanía de las fuentes y su mayor accesibilidad, como al hecho de que son víctimas conocidas en los pueblos y la gente demanda mucha más información, incluidas las fotos.

${ }^{4}$ Especializada en información local, cubrió ampliamente el asesinato de Carmen Vázquez Cereijo, publicando en la sección 'En Portada' del día 22 un total de 3 páginas, el día 23 ocupó la portada del diario y página completa en la sección 'Comarcas' y el día 24 página completa con tres fotografías. Informó sobre la mujer asesinada, con datos sobre su nombre y profesión, y se publicó una foto. Del homicida también se dieron a conocer datos personales, aunque no se facilitaron imágenes. Ejemplo de buen periodismo de investigación.

${ }^{5}$ Organización no gubernamental sin ánimo de lucro entre cuyas líneas de actuación se encuentra la prevención de la violencia de género. Declaraciones facilitadas a través de su Gabinete de Prensa.

\section{Referencias}

Asociación de Periodistas Gallegas (4 de septiembre de 2019). Entrevistador: Agustín López Vivas.

Castelló, R. y Gimeno, A. (2018). Manual de estilo para el tratamiento de la violencia machista y el lenguaje inclusivo en los medios de comunicación. Valencia: Unión de Periodistas Valencianos. Recuperado de http://bit.ly/2npKh2Z

Consejo Audiovisual de Andalucía (2016). Guía para el tratamiento informativo de la violencia de género. Sevilla.

Delegación del Gobierno para la Violencia de Género. Portal Estadístico: http://estadisticasviolenciagenero.igualdad.mpr.gob.es/ http://bit.ly/2odKyXo

El Correo de Andalucía (2019). Las asesinadas son un simple número. Recuperado de http://bit.ly/2Mli1H9

El Correo de Andalucía (2019). El maltratador siempre busca aislar a la víctima de sus familiares y amigos. Recuperado de http://bit.ly/2pVGcEL

El Español (2019). La vida de las víctimas. Recuperado de http://bit.ly/339JW3D

EFE https://www.efe.com/ 
Familiares de M. ${ }^{a}$ del Carmen Vázquez Cereijo (15 de agosto de 2019). Entrevistador: Agustín López Vivas.

Fundación Mujeres (20 de octubre de 2019). Entrevistadora: Rosa Rodríguez Cárcela.

Martínez Rodríguez, B. (2011). El tratamiento informativo de la violencia a la luz de los códigos deontológicos. Recuperado de http://bit.ly/2MjWij6

Pérez Rodríguez, C. (13 de agosto de 2019). Entrevistadora: Rosa Rodríguez Cárcela.

Rodríguez Cárcela, R. (2008). Del crimen pasional a la violencia de género: evolución y su tratamiento periodístico. Ámbitos. Revista Internacional de Comunicación, 17, 171-188. http://dx.doi.org/10.12795/Ambitos.2008.i17.11 